amount of decentralisation has been found advisable. Local committees of coal owners and others have been established in those areas where the Survey is already in operation.

The Fuel Research Board was called upon to render an important service in its early years, namely, to advise the Government of the day on the action to be taken in re-establishing the standards for the sale of gas, which had been suspended during the War. It was able, however, to avail itself of the comprehensive experimental study of the efficiency of different grades of gas in use, which had been carried out by the Joint Committee of the Institution of Gas Engineers and the University of Leeds. The recommendations it was finally able to make to the Board of Trade were embodied in the Gas Regulation Act of 1920, establishing the "therm" system of charging, which will undoubtedly in time be regarded as a landmark in the history of fuel industries in Great Britain. It has already had a great influence on the outlook of the British gas industry. The process of "steaming" the charge of vertical retorts came into prominence during the War years as a means of expanding the output of existing gas works plant, and led to much discussion in the gas industry. Eventually the Joint Committee mentioned above investigated the claims made for this process in a series of tests at Uddingston, which showed the uses and limitations of steaming. The Fuel Research Board has since then not only confirmed but also added to these results by the carbonisation with steaming of a variety of coals from different areas--a material contribution to the survey of carbonising coals. Work on the water-gas process has also been carried out at the Fuel Research Station.

The utilisation of fuel in domestic grates is so commonplace a matter that many will learn with surprise that until recently little precise scientific information was available, and some ideas popularly held are fallacious. Much of our quantitative knowledge is based on the experimental work initiated in I9I2 by the Manchester Air Pollution Board and carried on under its auspices for ten years-latterly with financial assistance from the Department of Scientific and Industrial Research. In 1922 the work was taken over by the Fuel Research Board, and the reports already issued have thrown much light on this important question.

Peat, steam-raising problems, internal combustion engines, alcohol, oil fuel, have all been the subjects of investigations by the Board. There is scarcely a branch of fuel utilisation which has not received some attention; and, indeed, a good idea of the "present state of the art" and the problems awaiting solution may be gained from a perusal of this report. The field of work is so wide that it is impossible for the research staff even of a national board to cover it in more than a fractional measure. It is gratifying to observe recognition of this in the allocation of financial assistance by the Board to independent workers in the universities and other centres of experiment. H. J. Hodsman.

\title{
Obituary.
}

Dr. W. E. HAWORTH.

$D^{\mathrm{R}}$ . WALLACE ELLWOOD HAWORTH, who, as a result of a collision between the motor cycle he was riding and a motor car, sustained fatal injuries at Salisbury, Southern Rhodesia, and died on March $\mathrm{r}_{3}$, furnished an example of a man who, possessing naturally a scientific bent, was able to devote himself wholly to scientific pursuits only somewhat late in life. He was sixty years of age at the time of his death and held the post of a Milner Research Fellow in entomology of the London School of Hygiene and Tropical Medicine, having, in accordance with the arrangement made between the School and the Government of Southern Rhodesia, been sent out to work in collaboration with Dr. G. R. Ross, who is engaged upon an inquiry into the etiology of blackwater fever. Dr. Haworth was responsible for the collection and identification of mosquitoes, and was gathering data showing how the distribution of anophelines coincided with the presence of cases of blackwater.

Dr. Haworth, who was born in New Zealand, had always been interested in zoology, a subject to which he devoted himself when at Canterbury College, Christchurch, from $\mathrm{x} 882$ until $\mathrm{I} 88_{5}$. He commenced the study of medicine at the University of Edinburgh in I886, graduated M.B., Ch.B. in 1892 , and then turned his attention to public health, taking his B.Sc. in that subject in 1893 . In the same year he was appointed examining officer for ships at Leith during an outbreak of cholera on the Continent. After two voyages to India as a ship's surgeon, he settled in private practice in Southern Rhodesia and was there from 1896 until r9r7. Throughout this period his interest in zoology was maintained and he was, to use his own words, constantly observing the life-histories of various insect pests.

From I9I7 until x919, Haworth was on active service with the Rhodesian Native Regiment in Nyasaland, German East Africa, and Portuguese East Africa, and thereafter was employed temporarily in Government service, holding the posts of M.O.H. Tanga, acting director of the Bacteriological Laboratory, Dar-esSalaam, and Medical Officer of Health at Lindi. Both at Tanga and Lindi his duties included those of Port Health Officer. It was especially at Dar-es-Salaam that he made his interesting and important researches on the breeding of mosquitoes in the tops of coconut palms. The results of his investigations were embodied in a carefully written paper which appeared in the Transactions of the Royal Society of Tropical Medicine and Hygiene in October I924. It is noteworthy that, despite his age, Dr. Haworth himself scaled coconut palms during the course of his observations. These have been the subject of some criticism, but are admittedly of a pioneer nature and were the means of bringing three new species of Aëdes to light.

Dr. Haworth returned to Great Britain in 1924 and then, full of energy and enthusiasm, took a course on systematic entomology under Prof. Ashworth. Thereafter, as has been recorded, he received an appointment at the London School of Hygiene and Tropical Medicine. During the few months he was in Salisbury he worked

NO. 2947, VOL. I I 7 ] 
with ardour at his special subject, made arrangements for extensive mosquito surveys, and collected a large amount of material. His tragic and untimely death has robbed the School of a zealous and well-trained research worker, and is greatly deplored by all who knew him.

\section{Mr. A. R. McCulloch.}

By the death of Allan Riverstone McCulloch, which took place at Honolulu on September I, I925, systematic ichthyology lost one of its foremost exponents. He was born at Sydney, New South Wales, on June 20, I885, and at the early age of thirteen he commenced work at the Australian Museum, Sydney, as an unpaid assistant. Even in those early days young McCulloch was distinguished by his enthusiasm, his ability, and his determination to succeed. Assisted and encouraged by Mr. Edgar R. Waite, then in charge of the vertebrate section of the Australian Museum, he made rapid progress both in the study of zoology and in drawing, and when, in 1906, Waite became Curator of the Canterbury Museum, New Zealand, McCulloch succeeded him, though he was then not quite twenty-one years old. By that time he had definitely resolved to devote himself to the study of fishes, and that became his life-work, though he was skilled in all branches of zoology, and was a recognised authority on decapod crustacea.

Exceedingly versatile, McCulloch was never satisfied with the second best, and became an expert photographer and kinematographer, an accomplished artist and musician, and a delightful lecturer. Although not of robust physique he was active and full of courage, and had made several adventurous trips to the Great Barrier Reef and various Pacific Islands. In I922, in company with Captain Frank Hurley, he traversed part of Papua, and returned with many valuable specimens and a wealth of observations on the natives and the animals of the island.

At the time of his death, McCulloch was on long leave granted him by the Trustees of the Australian Museum in the hope that his bodily and mental vigour would be restored. He left Australia to attend the Pan-Pacific Fisheries Conference at Honolulu, and, with his accustomed ardour, he took a leading part in the work; but he overworked himself and paid the penalty of enthusiasm in his chosen field of research.

When McCulloch died at the early age of forty years, he left behind a record of accomplishment rarely equalled in the full span of a human life. His work was marked by thoroughness and accuracy. Largely as a result of his numerous contributions, the taxonomy of Australian fishes has been placed on a secure foundation. Most of his work appeared in the Records of the Australian Museum or in the official publications of other State Museums in Australia. His most important work, which embodied the results of many years' toil and research, was his "Check List of the Fishes and Fish-like Animals of New South Wales," published by the Royal Zoological Society of New South Wales (Australian Zoologist, vol. I, rgr9, pp. 2 I7-227; vol. 2 , I92I, pp. 24-68; I922, pp. 86-I30). This fine piece of work was in 1922 issued separately as "Australian Zoological Handbook, No. I," and forms an enduring monument to the industry and ability of the author.

McCulloch had a most pleasing personality, and was ever ready to assist his colleagues. Many scientific workers, both in Australia and abroad, owed much to his helpful advice and criticism.

C. A.

\section{Mr. E. K. JORDAN.}

ERIC KNIGHT JORDAN, one of the most active and promising among the younger geologists of America, was killed in an automobile accident on March ro. Born in San Francisco on September 27, 1903, the son of David Starr Jordan and Jessie Knight Jordan, he had shown in early boyhood unusual interest in scientific research. Before he entered the university he had made a collection and prepared a manual of the molluscs of California. This MSS., still unpublished, contains much original work, especially on the chitons and the minute snails, Odostomia. His study of the molluscan fauna of Trinidad Head (Calif.) was written when he was fifteen years old, and was published by the U.S. National Museum.

Graduating from Stanford in I923, with geology as his major subject and zoology as a minor, Jordan made in 1924 , under the auspices of Cornell University, a large collection of fishes from Hawaii. Under the direction of the California Academy of Sciences, he took part in a biological and geological survey of the middle portion of Lower California. The reports on the last two expeditions are still unpublished.

A unique combination of heredity and environment made Eric Jordan a perfect specimen of young manhood. Handsome, vigorous, earnest, with a love for his chosen field of science which might be said to approach genius, he was heir also to the personal charm which has endeared his parents to numberless Stanford men and women. But a short month before his death he was married to an accomplished class-mate of his, Elizabeth Roper. The scientific world can but tender its respectful sympathy to one of its masters, so tragically bereaved, and mourn for so fair a promise, never to be fulfilled.

Albert Guérard.

WE regret to announce the following deaths:

Dr. S. M. Barton, professor of pure mathematics in the University of the South, and a charter member and past president of the Tennessee Academy of Sciences, on January 5, aged sixty-six years.

Prof. L. G. Gouy, of the University of Lyons, distinguished for his contributions to the theory of the propagation of spherical waves, the velocity of light and Brownian movements, on January 27, aged seventy-two years.

Prof. W. J. Lewis, F.R.S., senior Fellow of Oriel College, Oxford, and professor of mineralogy in the University of Cambridge, on April 16, aged seventynine years.

Dr. Carlo de Marchesetti, honorary director of the Museo Civico de Storia Naturale and director of the botanic garden, Trieste, on April 2.

$\mathrm{Mr} H$. Kirke Swann, author of a number of important ornithological works, including a "Monograph of British Accipitres," now in course of publication, on April I4.

NO. 2947, VOL. I 7 ] 